\title{
Divine Needs, Divine Illusions: Preliminary Remarks Toward a Comparative Study of Meister Eckhart and Ibn Al'Arabi
}

\author{
IAN ALMOND
}

Bosphorus University, Istanbul

A surprising number of Western studies or translations of the Sufi thinker and mystic Ibn Al'Arabi (1165-1240) make some kind of reference to the German preacher Meister Eckhart (1260-1327). The strength and conviction behind such references vary-while some simply mention Eckhart in passing, others (such as R. W. Austin) speak of "striking resemblances," while Richard Netton, in his 1989 work Allah Transcendent, goes so far as to call Ibn "Arabi "the Meister Eckhart of the Islamic Tradition."

There is certainly something exotic in bringing together two figures such as Eckhart and Ibn Al'Arabi; ecumenical agendas rightly find something reassuring in locating similarities between such diverse spiritual vocabularies as those of a Dominican preacher and a Sufi saint. However, the perfectly laudable desire to discern common elements among disparities is no justification in itself; however forcefully certain resemblances might strike us, it still remains to be seen whether such resemblances escape the superficial and point the way toward a deeper core of common thought.

Even without having read a word of either thinker's works, it is not difficult to see why so many scholars seem to link them together. These scholars both attempt a radical synthesis of the mystical with the philosophical; further, they subsequently suffer persecution from the authorities as a result. They both embark upon lengthy pilgrimages or journeys, lasting years (Seville to Damascus, Erfurt to Avignon); they even draw their own set of disciples after them (Suso, Tauler, Davud Al'Qayseri, al-Qushani) to commentate upon their works and disseminate their ideas. Even the modern critical debates concerning the two are analogous-arguments over

1. Fusus al-Hikem ["The Bezels of Wisdom"], trans. Ralph Austin (New Jersey: Paulist Press, 1980), p. 16. The Arabic edition used is A. E. Affifi's edition (Beirut: Dar al-kutub al-'Arabi, 1946). All page numbers to original are in bold. Ian Richard Netton, Allah Transcendent: Studies in the Structure and Semiotics of Islamic Philosophy, Theology and Cosmology (Routledge, 1989) p. 293. 
both thinkers' orthodoxy and their denominational status (Shi'ia or Sunni? Catholic or early precedent of the Reformation?), the same allegations of pantheism, the same questioning of their clarity and coherence as thinkers (Denifle/Affifi), the same comparisons with Far Eastern thought-systems (Suzuki, Ueda/Izutsu)—such superficially appealing similarities, although valid enough to invite comparisons, are still not enough to ground them. Therefore, the aim of this article is to briefly consider five possible areas in both thinkers' work where "striking resemblances" might lead to some genuinely similar foundations.

\section{ONENESS AND MULTIPLICITY: EINHEIT AND TAWHID}

As Neoplatonism plays a central role in the vocabulary of both thinkersEckhart as reader of Proclus and Dionysius, Ibn Al'Arabi as reader of Plotinus (via the famous Theology of Aristotle, actually the last five sections of the Enneads) - it is not surprising to find the oneness of God as a dominant motif in both thinkers' work. The main point to be made here is that, although both Eckhart and Ibn Al'Arabi present an all-encompassing Oneness which is the source of all multiplicity in the cosmos, Eckhart's version of this overflowing Oneness is more Neoplatonic and less Aristotelian than that of Ibn Al'Arabi.

"Do not let manyness veil you from the tawhid [unity] of Allah!" writes Ibn Al'Arabi in the Futuhat. ${ }^{2}$ Indeed, the immanence of God is displayed in His effects-effects that, however various, "spring[s] in reality from a single substance, its primordial substance." ${ }^{3}$ Whoever would seek gnosis must learn "to see the details in the whole" and also as "part of the whole." ${ }^{4}$ Thus, for Ibn Al'Arabi, multiplicity or kathra, correctly perceived, can ultimately lead one back to the source-which is where Eckhart's idea of the One's relationship to the multiple seems to differ. Although Eckhart naturally concedes that "God is One" (Deus unus est), and is happy to acknowledge how "all things and the fullness of being are in the One by virtue of its indistinction and unity," ${ }^{5}$ the possibility of returning to the One via the multiple never really emerges as a central idea in his work. There are certainly moments in the vernacular sermons where it occurs ("grasp God in all things, for God is in all things"), but they are outshadowed by a generally negative impression of the multiple, one which offers little promise of a breakthrough into the

2. William G. Chittick, The Sufi Path of Knowledge (Albany: SUNY Press, 1989), p. 155 (taken from the Futuhat al-Makkiyah II.619.11).

3. Fusus al-Hikem, p. 153.

4. Fusus al-Hikem, p. 47 , p. 48.

5. Oliver Davies, ed., Meister Eckhart: Selected Writings (London: Penguin, 1984), p. 259. 
God beyond God. 6 "Unity unites all multiplicity, but multiplicity does not unite unity." "Eckhartian multiplicity is the consequence of a fall, a descent from harmonious, ineffable purity into the fragmentary, impure confusion of this world; often used as a synonym for nothingness or creatureliness, such multiplicity has to be escaped, renounced, and purged before the soul can return to the One.

Ibn Al'Arabi, on the other hand, sees multiplicity as an extension of the One, even a development, as opposed to a fragmentary consequence of a divine overflow. The phenomenal world is no residual glimmer of a distant, once radiant source, but rather a constantly recurring possibility to obtain knowledge of the One through the many:

He commanded [His servants] only to seek knowledge of God by considering the engendered things which are temporally created. Each engendered thing gives them the knowledge of the divine relationship from which it became manifest. ${ }^{8}$

Hence the radically different attitudes toward the world in the works of Ibn Al'Arabi and Meister Eckhart. Whereas Eckhart dismisses any spiritual attention spent upon fallen multiplicity as a regressive move in the wrong direction ("Go out of this world and depart from all this toward which your soul still feels an inclination"9), Ibn Al'Arabi considers such an idea to be founded on ignorance ( jahil):

His ignorance makes him imagine that the cosmos is far removed from God and that God is far removed from the cosmos. Hence he seeks to flee (farar) to God. ${ }^{10}$

Ultimately, it is Eckhart's disbelief in the ability of the believer to reach God through His secondary causes-to glimpse, so to speak, the One's inward dimension (batin) through its outward (zahir) — that distinguishes the two thinkers' relationship toward oneness and multiplicity.

Why does such a distinction make Ibn Al'Arabi more Aristotelian? To understand this, one has first to grasp how the world of phenomena in

6. Reiner Schürmann, Meister Eckhart (Bloomington: Indiana University Press, 1978), p. 183: "nim got in allen dingen! wan got ist in allen dingen...." All German quotations will be taken from Niklaus Largier's two-volume edition of Josef Quint's selection, Meister Eckhart: Werke (Frankfurt am Main, 1993), Predigt, p. 30; Largier, p. 342.

7. James M.Clark, Meister Eckhart (London: Nelson \& Sons, 1958), p. 219: "einicheit einet alle manicvalticheit, aber manicvalticheit eneinet niht einicheit" (Predigt, p. 11; Largier, p. 134).

8. Chittick, Sufi Path, p. 156; Futuhat II.671.5.

9. Schürmann, Meister Eckhart, p. 51.

10. Chittick, Sufi Path, p. 158. 
the Great Sheikh's system is a constant, selective actualizing of the Divine Mind, which in Itself contains an infinite quantity of possible, nonexistent images ('ayna thabita), awaiting to be translated into corporeal reality. For Ibn Al'Arabi, creation is literally a constant marrying of the possible with the actual. In depicting this, Ibn Al'Arabi follows the Aristotelian privileging of actuality over possibility by introducing mercy (rahman) into his concept of creation. In an act of gratuitous kindness (imtinan), God relieves the possible things from the misery of nonexistence by bringing them into reality-by bestowing upon them, as Ibn Al'Arabi says, "the sweet pleasure of existence."11

It is difficult to find an equivalent of this in Eckhart, for whom creaturely multiplicity seems to be a diffusion of the purity of the One, and who seems to prefer the nameless to the named, the unexpressed to the actualized. Whereas in Ibn Al'Arabi the possible, nonexistent things clamor to be brought into existence, in Eckhart "they all clamor to return to that place from which they had emerged. Their whole life and being is a clamoring and a hastening back to Him from whom they were born." ${ }^{12}$ Ibn Al'Arabi, so to speak, emphasizes the outflowing (exitus), whereas Eckhart is more interested in the return (redditus), a return to the One not via the many, but rather through an emptying of the soul and an annihilation of the self. Differing attitudes toward multiplicity which, ultimately, belong to different cosmologies.

\section{GOD AS CONSTRUCT AND THE GOD BEYOND GOD: $A L-H A Q Q$ AND THE GOTHEIT}

A more compelling similarity can be found in the way both thinkers recognize a distinction between the God they believe in and a more primordial, radically unknowable source of divinity-in effect, a 'God' they can talk about and a 'God' they can not. However, once again the differences lie not so much in the common idea of 'God' as a construct, but rather in the two thinkers' attitudes toward this situation.

For Eckhart, the God we worship is certainly a God of truth, love, justice, and the like, a God we can pray to, imagine, and invoke. However, what Eckhart calls the Godhead (gotheit) is the silent, divine darkness prior to and beyond 'God', a nameless abyss bereft of characteristics which the soul must breakthrough to (durchbruch) if it is to experience true spiritual union with the One-hence Eckhart's cry: "I beg God to rid me of 'God'." As long as

11. Chittick, Sufi Path, p. 87.

12. Davies, Meister Eckhart, p. 130: "Die hânt alle ein ruofen, wider in ze komenne, dâ sie ûzgevlozzen sint. Allez ir leben und ir wesen daz ist allez ein ruofen und ein îlen wider ze dem, von dem zie ûzgegangen sint" (Predigt, p. 53; Largier, p. 568). 
we continue to think of God in terms of names, concepts, characteristics, images, we cannot truly experience the nameless, imageless ineffability of the Godhead-which is why Eckhart so often exhorts us to abandon metaphysical constructs in our search for a true spiritual encounter with the divine: "That we should forsake God is altogether what God intends, for as long as the soul has God, knows God and is aware of God, she is far from God." "13 Not only does Eckhart see God as a construct, but also as something which $o b$ structs, the Wittgensteinian ladder which, once we have climbed, we have to kick away from under us.

With Ibn Al'Arabi, although the initial idea remains the same, its evolution takes a slightly different course. In the final lines of the Fusus Al-Hikam, we read:

The God of beliefs is subject to certain limitations, and it is this God who is contained in his servant's heart, since the Absolute God cannot be contained by anything, being the very Essence of everything and of Itself. $^{14}$

The phrase "Gods of belief" is often employed by Ibn Al'Arabi. Earlier on in the Fusus we see it used:

When a person rationally considers God, he creates what he believes in himself through his consideration. Hence he worships only a God which he has created through his consideration. ${ }^{15}$

Our finite minds construct finite concepts (tasawwur) for God, concepts that spring from our limited, single perspectives of the all-encompassing One. However, whereas Eckhart sees this as a purely metaphysical affair-we instinctively give names like Good and Love to God-Ibn Al'Arabi discusses this on a much more personal level, suggesting that every individual creates his or her own individual God:

The great variety of beliefs is hidden from no-one. He who delimits Him denies Him in other that His own delimitation, while acknowledging Him only when He discloses Himself in that whereby he has delimited Him. ${ }^{16}$

Believers are ignorant insofar as they remain unaware, in the certainty of their utter self-conviction, of any other versions of God other than the God they worship (and here Ibn Al-Arabi is referring to, amongst others, the Ash'arites and the Mu'tazilites). They mistake their perspective for the bird's

13. Davies, Meister Eckhart, p. 244.

14. Fusus al-Hikem p. 284, p. 226.

15. Chittick, Sufi Path, p. 339.

16. Chittick, Sufi Path, p. 339. 
eye view, their singular interpretations for the final exegesis. This proposal that every believer's God is ultimately a God of his own making does have a skeptical flavor to it, and leads Ibn Al'Arabi to some radically apophatic statements which, if taken out of their context, could strike one as trenchantly pessimistic:

Hence you will see no-one who worships an unmade God, since man creates in himself that which he worhips and judges.

When a person sees something of the Real, he never sees anything but himself. ${ }^{17}$

However, it is precisely the difference between Eckhart and Ibn Al'Arabi on this point which saves such remarks from pessimism. Eckhart sees any kind of conceptualization of God as an injustice (unreht) upon His ineffability, and urges the believer to abandon 'God' as quickly as possible. Names such as Goodness and Truth clutter the Eckhartian soul, ideal state of which is an emptiness and openness (ledeger offenung) toward the Godhead. Images impede, names obstruct, concepts spiritually get in the way.

In contrast, Ibn Al'Arabi takes a far more benign view of the "Gods of belief," seeing them (perhaps more resignedly) as an inevitable consequence of our finitude. One sees here the greater degree of Godliness that Ibn Al'Arabi is willing to concede to the everyday world of phenomena; "correct behavior" does not consist in completely abandoning one's own beliefs as irrevocably false and idolatrous, but simply acknowledging their limitations and allowing for the possibility of other versions of God without denouncing them in favor of our own. Once the believer learns to do this, he or she can begin to see God not only in his own beliefs but in all other manifestations:

He who is more perfect than the perfect is he who believes every belief concerning Him. He recognizes Him in faith, in proofs, and in heresy ( ilhad), since ilhad is to deviate from one belief to another specific belief.

In other words, Ibn Al'Arabi is not asking God to rid him of 'God', but simply to rid him of his blinkers - the dogmatic convictions which prevent the believer from acknowledging the omnipresence of the One in everything around him. A gesture which, it should be noted, does not constitute a theological free-for-all, as Ibn Al'Arabi's own remarks on idolatry (shirk) bear out. Even the idolater, he says, worships God, albeit unknowingly. Because the Real (al-haqq) manifests itself in all things, even one who worships a stone or a tree worships God, the sin lies merely in one's obliviousness of the fact. It is difficult to imagine such a notion occurring to Eckhart.

17. Chittick, Sufi Path, pp. 351, 341. 


\section{THE DIVINITY OF THE SELF, THE DEPENDENCY OF GOD: THE $V U N K L E I N$ AND THE SECRET OF THE SOUL}

The greatest obstacle to writing with any degree of clarity about the divinity of the self in Eckhart and Ibn Al'Arabi lies precisely in the critical debates that have risen in the wake of the two thinkers, debates that highlight the ambiguity of both authors' remarks on the relationship between God and the soul. Thus, Nazis such as Alfred Rosenberg and Marxist critics such as Ernst Bloch (not to mention the Papal commission of 1327) perceived an Eckhartian soul that has the capacity to become God in every sense of the word, while critics such as James M. Clark consider such conclusions to be nothing but a willful misunderstanding of the Meister's message. Similarly, Ibn Al'Arabi's own views on the matter have long been a subject of debate. On the one hand, figures such as Mahmoud al-Ghorab see the Sheikh as a true "Muslim and a traditionalist (salafi)" 18 - one who would never dare to suggest that the soul may be as equally divine as its Creator, while others (such as Mustafa Tahrali) forced to admit to the Fusus contain a large number of "paradoxical expressions" concerning the relationship between God and the soul. ${ }^{19}$

In both thinkers' work the soul contains a mystery. For Eckhart "there is in the soul something very secret and hidden and far above it" - this is the famous "spark of the soul" (vunklein or scintillae anima) which in some sermons Eckhart says is created and in others uncreated. ${ }^{20}$ It is a fragment of the Godhead, bereft of attributes, images, and names, buried in the soul and constituting the only possibility for the soul to breakthrough to the Godhead-for, in typical Scholastic fashion, union can only come through likeness, and the soul possesses nothing else which is remotely like the Godhead.

Similarly in Ibn Al'Arabi the divine nature of the soul is also a secret which we carry about inside us: "He prevented the real secret from being known, namely that He is the essential Self of things. He conceals it by otherness, which is you." ${ }^{21}$ As in Eckhart, the idea of an exclusively transcendent God "out there" is an illusion, springing from a basic ignorance of one's own self. Hence the linking of self-knowledge with divine knowledge in Ibn Al'Arabi ("Who knows his self, knows his Lord"), which leads one in turn to the realization that God is both immanent and transcendent-in Tillich's

18. See al-Ghorab, "Muhyiddin Ibn al-'Arabi among Traditions and Schools of Thought," in Muhyiddin Ibn 'Arabi: A Commemorative Volume, ed. Stephen Hirtenstein and Michael Tiernan (Dorset: Element, 1993), p. 224.

19. See Mustafa Tahrali, "The Polarity of Expression in the Fusus al-Hikam," in Muhyiddin Ibn 'Arabi: A Commemorative Volume, ed. Stephen Hirtenstein and Michael Tiernan (Dorset: Element, 1993), p. 358.

20. Clark, Meister Eckhart, p. 193: "neizwaz gar heimlîches und verborgens und verre dar enhoben ist in der sêle" (Predigt, pp. 7, 92).

21. Fusus al-Hikem, p. 133, p. 110. 
terms, both the ontological (Augustinian) and the cosmological (Thomist) God. ${ }^{22}$ This sense of a common identity between creature and Creator in Ibn Al'Arabi is so strong that it results in a series of increasingly daring statements: "If we witness Him we witness ourselves, and when $\mathrm{He}$ sees us $\mathrm{He}$ looks on Himself," and "He worships me and I worship Him."23

For Ibn Al'Arabi, the precedent for such declarations was not a happy one. Al-Hallaj had famously pronounced "I am the Real" (anal Haqq) in Baghdad in 922, and had been executed by the authorities as a result. As one of the properties of God is to bestow Being upon things, the declaration of the divinity of the soul in both Ibn Al'Arabi and Eckhart enables both thinkers to make similar propositions-that we can hurt God, even kill Him, that His being is in some way dependent on our recognition of Him. In sermons such as Beati pauperes spiritu, Eckhart writes to this effect: "And if I myself were not, God would not be either. That God is God, of this I am a cause. If I were not, God would not be God." ${ }^{24}$ Words which, as John D. Caputo has pointed out, Hegel quoted approvingly in his Lectures on the Philosophy of Religion; Caputo even goes so far as to suggest that Eckhart started a tradition in German thought of 'God-dependent-uponMan' which, via Silesius and Hegel, was to reach Nietzsche and Marx. ${ }^{25}$ However, as most critics point out, the "God" Eckhart feels the soul can hurt and even kill is the accessible, knowable "God" (Ibn Al'Arabi's "God of Belief"), and not the primordial divinity of the Godhead. In other words, only our image of God is dependent upon our perception, not God Himself. This is a common enough defense of Eckhart's orthodoxy which, although perfectly valid, is slightly undermined by occasional remarks to the contrary (In Mulier venit hora, for example: "God has such a need to seek us out-exactly as if all his Godhead depended on it, as in fact it does."). ${ }^{26}$ Eckhart's inconsistent descriptions of the soul as sometimes created, sometimes uncreated (ungeschaffene) also complicates matters, particularly since Eckhart denied having ever described the soul as uncreated during his trial.

Why are we dwelling thus on the unorthodox possibilities in Eckhart's thought? Because, in a sense, their manifestation, alleged inconsistencies, and proposed resolutions have their equivalents in Ibn Al'Arabi. Like Eckhart, Ibn Al'Arabi presents a God who is in some way dependent upon us. In discussing the etymology of the word ilah (divinity), Corbin suggests

22. Fusus al-Hikem, p. 92, p. 81.

23. Fusus al-Hikem, pp. 55, 95; pp. 53, 83.

24. Schürmann, Meister Eckhart, p. 219: "und enwaere ich niht, sô enwaere ouch $<$ got $>$ niht. Daz got $<$ got $>$ ist, des bin ich ein sache; enwaere ich niht, sô enwaere got niht <got>" (Predigt, p. 52; Largier, p. 562).

25. John D. Caputo, The Mystical Element in Heidegger's Thought (Fordham University Press, 1978), p. 126.

26. Schürmann, Meister Eckhart, p. 58. 
the root wlh, "connoting to be sad, to sigh toward, to flee fearfully toward." ${ }^{27}$ This relates to a hadith or saying well known to Sufis: "I was a hidden treasure and I yearned to be known. So I created creatures in order to be known by them." Ibn Al'Arabi's most memorable expression of this is in the fifth chapter on Ibrahim in the Fusus Al-Hikam:

Where then is His Self-sufficiency, Since I help Him and grant Him Bliss? It is for this that the Real created me, For I give content to His knowledge and manifest Him. ${ }^{28}$

This denial of self-sufficiency to God causes some problems, as earlier in the Fusus Ibn Al'Arabi had isolated precisely this quality as "an incurable factor of distinction" between God and the soul. God creates us, while "He is free of all dependance whatsoever." ${ }^{29}$ And so, on the one hand we have a "careful" Ibn Al'Arabi, who cautiously attributes all the qualities of God to the soul except for that of maintaining existence; and, on the other hand, a more audacious version presents a soul that not only gives its Maker happiness and Self-knowledge but also enables Him to exist. As with Eckhart, one could remedy this by saying that the God of the first version is exclusively the Real (al-haqq), while the God of the second version which the soul supports and keeps in Being is merely the "God of belief." However, parts of the Futuhat seem to suggest that the soul genuinely could become one with the Real in substantia and not simply in grace. In speaking of the spiritually advanced who "have no station" (la maqam) Ibn Al'Arabi calls such believers "the divine ones (al-ilahiyyun), since the Real is identical with them." ${ }^{30}$ This seems to move fairly close to Eckhart's substantial linking of the Eternal Ground of the Soul with the Ground in the Eternal Godhead.

One final point should be stressed: although we have repeatedly used the word "become" in describing the soul becoming one with God, in both Ibn Al'Arabi and Eckhart, God and the soul always already belong to the same primordial source. A bond lies between them that precedes everything, even creation. Eckhart writes: "In my birth, all things were born, and I was the cause of my own self and and of all things." ${ }^{31}$ When the soul flows out of the Godhead and into the world, it acquires a name, a self, and a 'God'. It needs to "uncover the image of God" (gotes bilde in im entbloezende) buried in itself, in order to remember where it came from.$^{32}$ In other words, a latent divinity in the soul has to be actualized. A.E. Affifi probably expresses this

27. Henry Corbin, Creative Imagination in the Sufism of Ibn 'Arabi, trans. Ralph Manheim (Princeton, NJ: Princeton University Press, 1969), p. 112.

28. Fusus al-Hikem, p. 95 , p. 83.

29. Fusus al-Hikem, p. 55.

30. Chittick, Sufi Path, p. 376.

31. Davies, Meister Eckhart, p. 208.

32. Davies, Meister Eckhart, p. 150 (Predigt, p. 40; Largier, p. 430). 
idea best in relation to Ibn Al'Arabi:

when Ibnul'Arabi talks of mystical union with God he means a "state" in which an already existing union is being realized or verified. The mystic does not become God, for there is no becoming in Ibnul'Arabi's theory, he is essentially one with God in the sense everything else is. ${ }^{33}$

Given the fact that the central aim of Affifi's study is to portray Ibn Al'Arabi as a "thoroughgoing pantheist," one could dismiss this surmise of the Great Sheikh's relation to God on the basis of everything else Affifi has said. Nevertheless, it is difficult not to receive this impression from certain parts of the Fusus - especially the tenth chapter on Hud, where otherness is understood as an illusion, constructed by God, to hide the true nature of the soul's divinity from itself: "He prevented the real secret from being known, namely that He is the essential Self of all things." 34 Whenever we say "you" to God, we perpetuate this illusion of alterity, the mistaken conviction that God is somehow other and separate from us. Hence, although Ibn Al'Arabi does not quite express his idea of the soul in terms of a fragment of the Godhead, spilling out of nameless unity into the world of the multiple, his notion of the soul's 'secret' (sirr) relationship with God, a common identity anterior to the soul's beliefs about itself, does appear to have a common structure with Eckhart.

\section{CENTERLESSNESS AND WANDERING}

Exactly how does the motif of wandering manifest itself in Eckhart's sermons? Furthermore, do they correspond to any of the ideas presented in Ibn 'Arabi's various conjectures upon the Straight Path (al-sirat al-mustaqim)? It is not difficult to imagine how Eckhart's sermons-with their emphasis on spiritual spontaneity, divine aimlessness, unconditional actions and the ontological 'opening' and 'emptying' of oneself to God-can be considered examples of a 'wandering thought'. Sermons which have not only directly inspired titles such as Reiner Schürmann's 1972 Maitre Eckhart ou la joie errante, but also Angelus Silesius's famous Cherubinic Wanderer, whose poem "The Rose is without Why: it blooms because it blooms" is written in clear homage to the Eckhartian tenet of the sunder warumbe, the "without-why."35 The term pathless way (wec âne wec) is mentioned in Eckhart's sermon Intravit Iesus in quoddam castellum - the pathless way which "is free and yet fixed, in which we are raised and exalted above ourselves and all things, with neither will nor images" (vrî und doch gebunden, erhaben und gezucket vil nach über sich

33. A. E. Affifi, The Mystical Philosophy of Ibn Al'Arabi (Cambridge: Cambridge University Press, 1939), p. 140-41.

34. Fusus al-Hikem, p. 133.

35. For more on the link between Angelus Silesius and Eckhart, see Caputo, Mystical Element, pp. 97-99. 
und alliu dinc âne willen und âne bilde) ${ }^{36}$ Eckhart's phrase is deliberately paradoxical, and in this, it reflects what Eckhart sees as both the necessity of a spiritual direction and the danger that such a direction will be codified and institutionalized into a doctrinal path. Can we arrive at where we want to go without adhering to such paths? In such an adherence to the itinerary, Eckhart seems to perceive a certain danger: "For whoever seeks God in a special way gets the way and misses God" (Wan swer got suochet in wîse, der nimet die wîse und lât got). ${ }^{37}$ Eckhart sees a path to God as potentially becoming more important than God Himself. In following such a path, one risks deifying it, idolizing it, transforming it into the object (and the end) of one's attentions.

Thus Eckhart's pathless way is not an incitement to moral abandon or self-indulgence, but an attempt to find a different, wayless way of breaking through to the Godhead, free of images, concepts, and doctrines. The errant, therefore, is not necessarily erroneous. One is tempted to ask: when do people err (sinfully) in Eckhart, if such pathlessness is seen as spiritually enhancing? Eckhart's response to this, in one sermon, is to stress the need for the soul to be free of all conceptions of God, self and external obligations. "Therefore the only reason why anyone has ever erred in anything is that they have departed from this and have turned too much to external things." ${ }^{38}$ In order to breakthrough to the Godhead, the soul must be as "free and untrammeled" as God is, which is where, as we will see, the Eckhartian theme of detachment takes on a central role, distinguishing itself from the attachment to a "special way." In short: people only ever err, for Eckhart, when they methodically follow a path.

Why does Eckhart urge us along his pathless way? Why is the ramble superior to the journey, the uncertainty of the peregrinary preferable to the destination of the pilgrimage? Eckhart's suspicion of the pathbound and the goal-orientated (a suspicion which translates "destination" as "motivation") as ultimately constituting that which sterilizes and reifies faith, is one response to this question. However, on a much more basic level, Eckhart's affirmation of errancy lies in conjunction with his desire to breakthrough to the Godhead: to wander, in the Eckhartian sense, is to imitate God. This, in turn, means that if God is a divine uncertainty, then we must become a kind of uncertainty ourselves.

In order to understand this better, two points need to be made-first of all, a standard motif in Christian thought is the desirability of the soul's likeness to God. The soul is born in a state of unlikeness-Augustine's regio dissimilitudinis - and must strive to resemble increasingly its Creator in order

36. Davies, Meister Eckhart, p. 197 (taken from the sermon Intravit Iesus in quoddam castellum [Sermon 86 in Quint 3:486]).

37. M. O'C. Walshe, Meister Eckhart: German Sermons and Treatises (London: Watkins, 1979). 1:117 (from In hoc apparuit caritas dei in nobis [Predigt, p. 5b, Largier, p. 70]).

38. Davies, Meister Eckhart, p. 217, from the sermon Ubi est qui natus est rex judaeorum? 
to achieve union with it. ${ }^{39}$ Eckhart is in perfect accordance with this: "Our masters say union presupposes likeness. Union cannot be without likeness" (Daz sprechent unser meister: einunge wil haben glîchnisse. Einunge enmac niht gesîn, si enhabe glîchnisse). ${ }^{40}$ It is only through identity with God that Eckhart can achieve the birth of God in the soul: "A master says: all likeness means birth. He says further that like is not found in Nature unless it is born."41 In order to undergo the mystical experience of engendering God in the ground of the soul, the soul must become like God.

Secondly, the Eckhartian Godhead which the wandering soul imitates is nameless, place-less, image-less. It has no origins and no destination. Just as all the effects of the Godhead are unconditional and unmotivated, a simple "overflowing"-God's love essentially being "without why"—so must all our actions and words be bereft of result-seeking motives and expectations. To have no destination, to not care about one's origins, is a step toward the divine.

If the likeness of the soul to God is essential as a prerequisite to their union, and if such a God is a divine no-thingness, aimlessly ebullient, we can begin to understand why Eckhart sees errancy as anything but error. Schürmann writes: "Identity is gained only this way; identity with God is wandering." ${ }^{2}$ The fact that the Eckhartian Godhead possesses no coordinates, cannot be linked to a particular shrine or mountain top, reinforces Eckhart's preference for the wanderer over the pilgrim:

A pagan master says: the nothingness of God fills all things while his somethingness is nowhere. And so the soul cannot find God's somethingness unless first she is reduced to nothingness wherever she may be... Therefore a master says: whoever wishes to come to God should take nothing with him. ${ }^{43}$

It is a passage which, in many ways, reminds one of Borges's essay on the non-location of the deity "The Fearful Sphere of Pascal" ("God is a fearful sphere whose center is everywhere and whose circumference is nowhere”). ${ }^{44}$ If God's "somethingness" is no-where, then whoever wishes to find this "somethingness" must forget the pilgrimage, must abandon all their itineraries, must rid themselves of any notion of where-for God lies "nowhere." The passage cited could be redescribed as an urge to abandon the ontotheological center we rely on to furnish our conceptions and images of God, in virtue of a spiritual centerlessness, one which would let God be God.

39. From Confessions, Bk. 7, chap. 10.

40. Walshe, Meister Eckhart, p. 163, from the sermon Postquam completi erant dies (Sermon 44 in Quint 2:338).

41. Walshe, Meister Eckhart, p. 164.

42. Schürmann, Meister Eckhart, p. 47.

43. Davies, Meister Eckhart, p. 247.

44. Jorge Luis Borges, Labyrinths, trans. Donald A. Yates and Jane A. Isby (London: Penguin, 1995), p. 227. 
How does this attitude toward wandering differ from that of Ibn Al'Arabi? At first glance, it seems that the Great Sheikh is saying the exact opposite. In accordance with the Koran's various exhortations concerning the One True Path, Ibn Al'Arabi appears to associate pathlessness with a kind of ignorance, rather than any form of purer enlightenment:

Men may be divided into two groups. The first travel a way they know and whose destination they know, which is their Straight Path. The second group travel a way they do not know and of whose destination they are unaware, which is equally the Straight Path. The Gnostic calls on God with spiritual perception, while he who is not a Gnostic calls on Him in ignorance and is bound by a tradition. ${ }^{45}$

Such ignorance of the true path is qualified, as ever in Ibn Al'Arabi, by the omnipresence of God. The author of the Fusus never tires of quoting the verse Wheresoever you turn, there is the face of God (2:115) - a verse which helps us understand exactly why Ibn Al'Arabi is tolerant toward a multiplicity of paths. ${ }^{46}$ If God truly is the "essential Reality" of all things, then no path is crooked, for every path ultimately leads one back to God ("Certainly, all roads lead to Allah, since He is the end of every road"). ${ }^{47}$ If, for Eckhart, the pilgrimage is an illusion because God's center is nowhere, wandering is redeemed for Ibn Al'Arabi because God is everywhere. If God is omnipresent in all things, then errancy can never truly be error.

All of which, however, still does not mean that Ibn Al'Arabi shares Eckhart's advocating of the pathless. All paths lead to God, though not all paths lead to felicity. Only the road which follows the Law (al-mashru'a) can accomplish this-what is important, however, is not to forget the correct attitude we should maintain while walking such a path. In praying numaz, for example, we should still continue to pray toward Mecca:

However, do not tell yourself that $\mathrm{He}$ is in that direction only, but rather maintain both your attitude in facing the sacred mosque and your attitude to the impossibility of confining His face to that particular direction, it being merely one of many points toward which men turn. ${ }^{48}$

There is a wariness here toward directions and destinations which does seem to share a common spirit with Eckhart. The mistaken belief that Allah lies only in the direction of Mecca can threaten to blind the Gnostic to the true infinity of God, just as the Eckhartian believer who adheres too closely to a particular way "gets the way and misses God"-even if, for Ibn Al'Arabi,

45. Fusus al-Hikem, p. 132, p. 105.

46. Cited in Fusus al-Hikem, p. 137, p. 113.

47. Chittick, Sufi Path, p. 303.

48. Fusus al-Hikem, p. 138, p. 114. 
overt devotion toward a particular path doesn't cause the believer to "miss" God, but simply to "restrict" Him. For the Great Sheikh the problem is not so much the path, but rather our attitude toward it.

In relation to the motifs of centerlessness and wandering in the two masters, two final points need to be made concerning similarity (tashabbuh) and bewilderment ( hayra). Like Eckhart, Ibn Al'Arabi places great emphasis on the need for the soul to become "similar" to God-however, what the Sufi understands by the term tashabbuh is quite different from Eckhart's idea of similarity. As we saw, Eckhart's aim for the soul is to be as "free and empty" (ledic und vri) as God is-as free of names, images, and directions as the Godhead. Ibn Al'Arabi, however, generally uses the term "similar" as a synonym for his own exhortation to "assume the traits of the divine names" (al-takhalluq bi'l-asma' al-ilahiyya). As the soul already possesses all of the Divine Names of Allah in potentia-Patience, Love, Mercy, and the like-the duty of the soul is to become similar to God by actualizing these latent qualities in itself. In other words, for Eckhart "similarity to God" means to get rid of names and attributes, whereas in Ibn Al'Arabi it means to acquire them.

It should also be remembered that, for Ibn Al'Arabi, all paths ultimately end in bewilderment ( hayra). This is the bewilderment of one who is finally immersed in the infinity of God and engulfed by the all-encompassing perplexity of the Divine-a state best described by the author of the Fusus in his chapter on Moses:

[True] guidance means being guided to bewilderment, that he might know that the whole affair [of God] is perplexity, which means perturbation and flux, and flux is life. ${ }^{49}$

If God is perplexity-and all roads lead to God-then the ultimate destination of all paths is a "non-destination." In short, one embarks upon a path in Ibn Al'Arabi not to find oneself, but to lose oneself. Ibn Al'Arabi calls this "drowned in the seas of the knowledge of God." $" 50$ Thus the path is actually a temporary means to a permanent pathlessness. Nowhere, however, does Ibn Al'Arabi advocate a centerless wandering as a means of obtaining union with the divine.

\section{INFINITE HERMENEUTICS: SEAS WITHOUT SHORES}

In the otherwise thoughtful and informative introduction to his translation of Ibn Al'Arabi's Shajarat al-Kawn, A. Jeffrey writes how

49. Fusus al-Hikem, p. 254, p. 200.

50. Fusus al-Hikem, p. 79. 
[Ibn Al'Arabi's] curious exegetic methods in interpreting passages from the Quran ... are not sufficiently different from similar arbitrary exegesis of the Bible in Jewish and Christian circles ... to merit special comment. $^{51}$

First of all, neither Ibn Al'Arabi nor the "Jewish and Christian" exegetes Jeffrey refers to would ever have described their labors as "arbitrary"; every nuance, etymology, and symbol gleaned from the sacred text had a very clear purpose and meaning for the medieval reader, however far-fetched and "arbitrary" such interpretations might seem to the modern eye. Secondly, the fact that both Eckhart and Ibn Al'Arabi, amongst many others, believed in an infinitely readable Text does not mean they are "not justifiably different ... to merit special comment." Declaring a text to possess an infinite number of meanings is one thing-the various reasons why one believes this to be the case is quite another. The point I want to make in this final section lies precisely in the different reasons why both masters believe in the endless texts of their respective holy scriptures. Eckhart and Ibn Al'Arabi's positions on the (un) knowability of God and their different understandings of His ineffability, I hope to show, are perfectly replicated in their respective hermeneutics. For both masters, the semantic inexhaustibility of the divine text is simply an extension of what they have already said about the Divinity itself.

In writing about the infinite hermeneutics of Ibn Al'Arabi, it becomes difficult to avoid mentioning a rather sharp disagreement amongst critical scholarship as to exactly how flexible Ibn Al'Arabi's hermeneutics actually are. The disagreement centers over the use of a certain term, $t a$ 'wil, which literally means "carrying back to" but which generally refers to a rather mystical and esoteric technique of exegesis, more often than not associated with Shi'i Islam. The practice of ta'wil encourages the idea of a text with an infinite number of inner meanings (batin) - rather than interpreting the text, the $t a$ 'wil releases it, leading the reader onto a whole new level of higher meanings. The main proponent of such a version of Ibn Al'Arabi has been Henry Corbin. As Corbin spent many years teaching in Iran, most critics tend to see Corbin's linking of Ibn Al'Arabi with ta'wil as part of his general desire to present the Great Sheikh as "a pure Shi'ite."52 Chittick, most notably, opposes this idea with the observation that most of Ibn Al'Arabi's references to ta'wil in the Futuhat are actually explicitly negative. Of course, Chittick's knowledge of his subject and the quality of his scholarship are beyond question; however, in his opposition to Corbin, Chittick feels compelled to make some slightly incredible claims for the orthodoxy of Ibn Al'Arabi's hermeneutics-in particular, that he "displays a tremendous reverence for the literal text."53 Any reader of the Fusus Al-Hikam, with its mystical numerologies, strange etymologies, obscure

51. A. Jeffrey, trans., Shajarat al-Kawn (Lahore: Aziz, 1980), p. 25.

52. Corbin, Creative Imagination, p. 26.

53. Chittick, Sufi Path, p. xvi. 
interpretations, implicit criticism of Noah, and apparent praise for the tyrannical Pharaoh, may be forgiven for thinking otherwise.

One of the first differences that strikes one between the hermeneutics of Ibn Al'Arabi and Meister Eckhart is that Eckhart, unlike his Sufi counterpart, actually says relatively little about the act of interpretation itself. Whereas long sections of the Futuhat are given over to a self-conscious and rigorous examination of all the problems of interpretation and their various implications, Eckhart seldom analyses the activity of exegesis-most of his thoughts on this subject presented in the German works are restricted to two or three sermons. What does unite the two thinkers, however, is a common tendency to reinscribe popular phrases and stories from the Koran and the Bible into their own thought-systems by imposing radically different interpretations upon them. Thus, Eckhart will interpret Jesus' casting out of the money-lenders as the need to clear (empty) the temple (ground of the soul) of all unwanted inhabitants (concepts, names, images) before Christ can enter it (the divine birth of the logos in the ground of the soul). In a similar way, Ibn Al'Arabi will reinterpret an apparently straightforward verse such as Fear your Lord (4:1) as meaning "Make your outer selves a protection for your Lord, and make your inner [reality], which is your Lord, a protection for your outer selves." 54

We have already seen how Eckhart's version of the Godhead forever recedes before whatever proposition we try to make about it. "If you visualize anything or if anything enters your mind, that is not God. Indeed, he is neither this nor that." ${ }^{55}$ God remains radically Other to whatever we try to say, sing, murmur, or paint about Him. An apophatic theology which, interestingly enough, Eckhart reinforces with reference to a venerated "heathen master," the eleventh century Islamic philosopher Avicenna (Ibn Sina): "God is a Being to whom nothing is, or can be, similar." 56 This idea of a God about Whom our assertions are forever incomplete is reflected in Eckhart's hermeneutics, where he suggests that the biblical text may well have a progressively infinite number of meanings:

there is none so wise that when he tries to fathom it, he will not find it deeper yet and discover more in it. Whatever we may hear, and whatever anyone can tell us, contains another hidden sense. ${ }^{57}$

54. Fusus al-Hikem, p. 57, p. 56. One cannot help but think of Heidegger here, who can take a fragment from the Pre-Socratics such as Anaximander's "Here, too, the gods come to presence" (einai gar kai entautha theos) and reinterpret it to mean a much more Heideggerian "The familiar abode for man is the open region for the presencing of god." See Heidegger's "Letter on Humanism," in Basic Writings: Martin Heidegger, ed. David Krell (London: Routledge, 1978), p. 258.

55. Schürmann, Meister Eckhart, p. 125.

56. Clark, Meister Eckhart, p. 179 (taken from Avicenna's Metaphysicae, Lib. ix, chap. 1).

57. "vnnd es ist auch niemant so weyss, der sy gründen woll, er fynde sy tieffer vnnd fynde mer darinn. Alles, das wir hie horen mogen, vnnd alles, das man vns gesagen mag, das hat 
The analogy for the scriptures that Eckhart moves close to here-that of a bottomless, unfathomable ocean-has its precedents in both Islamic and Christian traditions (most notably in Origen and Al-Ghazali) ${ }^{58}$ What is distinctive about Eckhart's passage is the faint sense of futility with which he imbues the interpretive act. Unlocked secrets only ever lead to more secrets, which lead to more, ad infinitum. Or, in Sufi terms, the comprehension of the zahir yields no batin, but simply an endless succession of more zahir, without any hope of ever "touching the bottom." No small wonder, then, that Eckhart described the Godhead as an "abyss," that which is literally without end ( $a b$-grunt). Like the Godhead, the Holy Scriptures are one such abyss - a book whose meanings have no conceivable end.

The spirit of Ibn Al'Arabi's hermeneutics has the same mood of limitlessness about it, if for radically different reasons. Like Eckhart, Ibn Al'Arabi's hermeneutics cannot be separated from his theology. We have seen how the "essential Reality of God lies in all things," and consequently how the omnipresence of God lies in all directions. Ibn Al'Arabi's hermeneutics translate this divine omnipresence into purely textual terms-if the Reality of God lies in all things, and if the center of God lies in all directions, then the intention of God lies in all interpretations:

We say concerning the senses of a verse that all are intended by God. No one forces anything upon God ... The reason for this is as follows: The verse of God's speech, of whatever sort it might be-Koran, revealed book, scripture, divine report-is a sign or a remark signifying what the words (lafz) support in all senses and intended by the One who sent down His speech in those words.... For He who sent it down knows all those senses without exception. He knows that His servants are disparate in their consideration of those words.... Hence, when someone understands a sense from the verse, that sense is intended by God in this verse in the case of the person who finds it. ${ }^{59}$

Just as Ibn Al'Arabi allows for the validity of an individual's finitizing conception of God, in a similar way he is equally tolerant of our finite understandings of the infinite text. Our single perspective confines us to

alles eynen anderen, verborgenen synn darinn" (M. O'C. Walshe, Meister Eckhart:German Sermons and Treatises [London: Watkins, 1979], 2:250; Sermon 51 in Quint 2:467).

58. In his Aesthetics of Thomas Aquinas, Eco reels off an impressive series of instances in medieval thought where the scriptures were portrayed as a source of endless meaning. St. Jerome considered the scriptures to be an "infinite forest of meaning," Origen referred to them in his In Genesin Homiliae as "a mysterious ocean of the divinity," while Gilbert of Stanford thought of the Bible as a fast flowing river, which constantly produced new meanings. See Umberto Eco, The Aesthetics of Thomas Aquinas, trans. Hugh Bredin (London: Radius, 1988), p. 145. An examination of AlGhazali's reference to the Koran as a "sea without a shore" can be found in Gerald Bruns, Hermeneutics Ancient and Modern (New Haven, CT: Yale University Press, 1993), pp. 124-37.

59. Chittick, Sufi Path, p. 244. 
a single understanding, whereas the Divine Author has comprehended all possible senses. Therefore, as in Eckhart, our interpretation of the text is forever incomplete, but for different reasons. In Eckhart, the real meaning of the text is never reached; its promise always recedes from the interpreter into infinite possibility, forever eluding the actualizing gaze of the exegete just as the radical alterity of the Godhead eludes all of our expressions. The interpreter of the Bible is forever undermined by the existence of another "deeper" and "hidden" sense.

This undermining or belittling of the finite interpretation simply does not take place in Ibn Al'Arabi. There are no perpetually "deeper" senses, but simply an infinite range of alternative ones. The "shoreless ocean" of the Koran comprises all things-as the Koran itself says, We have missed nothing out (6:38). In Ibn Al'Arabi's word, it is the book which, "to the exclusion of all other books, alone possesses all-comprehensiveness (jami'yya)." ${ }^{\prime \prime 0}$ An interpretation is one aspect of this immense infinity, one which retains its relative validity and is never diminished or flawed by some perpetually "other" sense.

\section{PROVISIONARY CONCLUSIONS}

These brief and somewhat cursory remarks constitute only the beginning of a comparative study of the two thinkers. Not only do they remain undeveloped, but many more possible similarities have not even been touched upon-the concept of self-annihilation (fana, niht-werdenne) and union with the divine (ittisal, einunge) in both thinkers, the 'continuous' idea of creation that plays a central role both in Eckhart (the continuous birth of the Son in the Ground of the Soul) and Ibn Al'Arabi (the renewal of creation in each instant), notions of preparedness (istidad, bereitschaft) and openness (futuh, offenung), not to mention the various stylistic metaphors and analogies which both writers frequently make use of (water/cup, mirror/reflection, kernel/shell, clothing/nakedness, and so on). Equally importantly, some significant differences between the two figures have not been articulated. The various stations and waystations (maqam, manzil) of the spiritual path, for example, which Ibn Al'Arabi copiously annotates and painstakingly elaborates upon in the Futuhat, never really enjoys the same amount of attention in Eckhart. Apart from the brief descriptions of the soul's journey at the beginning of On the Nobleman, the word 'stage' (grât) occupies no central role in the Dominican's thought, the metaphor of the "breakthrough" (Durchbruch) supplying the dominant image for Eckhart's idea of divine knowledge.

Another important difference which would merit further investigation is the distinctive (and doubtless provocative) way in which Eckhart describes

60. Chittick, Sufi Path, p. 239. 
the Godhead as a "darkness" (vinsternisse), a "nothingness" (niht), a "desert" (wuste) and an "abyss" (abgrunt), substantives which the Sufi never really attributes to God. For Ibn Al'Arabi, "God is sheer light [ nur], while the impossible is sheer darkness [zulma]," ${ }^{61}$ even though in some places he does describe the names of incompatibility (tanzih) as a collection of "darknesses." 62 Ibn "Arabi never really calls God a "desert," although in his "Book of Majesty and Beauty" (Kitap al-jalal wa-l Jamal) he does say how "there is no relationship [between the temporal and the eternal] in the deserts of bewilderment of this majesty." ${ }^{63}$ Nor does Ibn "Arabi really stress the idea of God as a darkness, although Izutsu dedicates a central chapter of his famous study to the "Abysmal Darkness" in Ibn 'Arabi, although the word he uses-' $a m a$ '-is more often employed by the Sheikh's disciple, al-Qunaishi. ${ }^{64}$ The closest Ibn Al'Arabi comes to calling God a kind of nothingness is the tradition "God is, and nothing [la shay] is with Him," although this is more an account of how entities cannot persist in their being once they reach the presence of the Real, rather than any description of the Real itself. ${ }^{65}$ And finally, even though Ibn Al'Arabi never explicitly calls God "an abyss," he does use in the Fusus the word hawa for divine passion. A word whose Arabic root, as Austin points out, contains the meanings "to fall headlong," "to be wide and deep," and "abyss." 66

Three points, for now, can be drawn from a comparison of the vernacular writings of Meister Eckhart with the Fusus al-Hikam and Futuhat of Ibn Al'Arabi. First of all, although both writers constantly emphasize the Oneness of God, their idea of the relationship between this Oneness and the multiple is fundamentally different. Whereas Ibn Al'Arabi perceives the presence of God in all things-and understands this presence as a completely valid opportunity to glimpse the whole through the fragments-Eckhart's world is only of use insofar as it can tell the soul not what God is, but only what $\mathrm{He}$ is not. In Ibn Al'Arabi God permeates the world of phenomena, whereas in Eckhart the world simply reflects, in a negative, apophatic way, the radical otherness of God. Secondly, both thinkers make an identical distinction between a God we construct—a God we can talk about—and an unspeakable, attribute-less 'God' prior to this divinity. However, whereas Eckhart insists we have to abandon this construct if we are truly to acquire divine knowledge, his Sufi counterpart only sees the "God-as-construct" as an obstacle if we fail to realize there is "Someone" beyond it which supersedes our understanding. Once we realize the "actual situation," then our worship of the

61. Chittick, Sufi Path, p. 214.

62. Chittick, Sufi Path, p. 58.

63. Rabia Terri Harris, trans. "Book of Majesty and Beauty," Journal of the Muhyiddin Ibn 'Arabi Society 8 (1989): 25.

64. See T. Izutsu, A Comparative Study of the Key Philosophical Concepts in Taoism and Sufism, 2 vols. (Tokyo: Keio University, 1967).

65. Chittick, Sufi Path, p. 364.

66. Fusus al-Hikem, p. 242. 
God we construct is no longer idolatrous. Thirdly, the belief that a secret, latent part of the soul actually enjoys a privileged and anterior relationship with the Real/Godhead, a relationship ranging in various instances from the analogous to the substantial, offers the most convincing point of similarity between the two vocabularies. Particularly since all the implications arising from such a tenet-that God is vulnerable, dependent upon us, that we in turn can kill God, hurt Him, deprive Him of His Being-are considered and developed by both authors.

The spirit of these distinctions seem to suggest the following: if Ibn Al'Arabi's God is known by all names, then Eckhart's God is known by no name. If Ibn Al'Arabi's God lies in all directions, then Eckhart's God can be found in none of them. The consistent Sufi emphasis on "the essential Reality [lying ] in all things" - a belief I refrain from labeling "pantheism"forces apart two otherwise compatible critiques of metaphysical thought and rational consideration, gently pushing them in opposite directions. Even in less centrally-located areas of their thought such as pilgrimage and hermeneutics, this can be discerned. The omnipresence of Ibn Al'Arabi's God renders all (justifiable) interpretations acceptable, and all directions as God-filled as Mecca's. Whereas Eckhart's scriptures will forever hide something elusively Other from the exegete-whereas Eckhart's wanderer will see all his destinations as ultimately rendered irrelevant by the non-location of the Godhead-the Sufi master seems to be suggesting, through similar terminology and from an identical point of departure, a significantly different direction. 